\title{
ПЕДАГОГИЧЕСКИЕ УСЛОВИЯ РАЗВИТИЯ ЛИЧНОСТИ ПОДРОСТКА НА ЗАНЯТИЯХ ХОРЕОГРАФИЕЙ
}

\author{
Р.А. Зюкина \\ Московский гуманитарный университет
}

\begin{abstract}
Аннотация: $B$ статье автор выявляет педагогические условия, способствующие формированию иенностных ориентаций, развитию волевых, нравственных качеств личности подростка на занятиях хореографией.

Ключевые слова: педагогические условия, развитие личности подростка, хореографическое искусств
\end{abstract}

\section{PEDAGOGICAL CONDITIONS FOR THE DEVELOPMENT OF A TEENAGER'S PERSONALITY IN CHOREOGRAPHY CLASSES}

\author{
R.A. Zyukina \\ Moscow University for the Humanities
}

\begin{abstract}
In the article, the author identifies pedagogical conditions that contribute to the formation of value orientations, the development of strong-willed, moral qualities of a teenager's personality in choreography classes.
\end{abstract}

Keywords: pedagogical conditions of development of the personality of a teenager choreography

В условиях развития современного общества, в период культурной глобализации, модернизации и внедрения инновационных методов в образовании возникает необходимость в обновлении системно-деятельностного подхода в обучении и воспитании молодежи. Необходимо сделать акцент напсихологических характеристиках личности подростка, способности к адаптации, развитии морально-этического воспитания подрастающего поколения.

Эффективность такого подхода проистекает из возможности разностороннего образования, повышения мотивации и интереса подростков к обучению хореографии, создания условий для общекультурного и личностного развития.

Хореография - одно из эффективных средств саморегуляции и гармоничного развития личности в подростковом возрасте. В процессе формирования личности подростка на занятиях хореографией вырабатывается умение справляться со своим психоэмоциональным состоянием, умение выражать себя и принимать свою личность (Пуртова, 2003).

Хореографические занятия повышают уровень культурной грамотности, формируют у подростка эмоциональную культуру, лидерские и организаторские способности. Они наполняют жизненными силами и жизненной энергией, дают чувство самодостаточности и развивают самопознание.

Занятия танцами развивают чувство прекрасного, учат не только видеть 
красоту, но понимать и создавать ее, образуют поле для развития образного мышления, развивают фантазию, грациозность движений, улучшают физическую форму, позволяют влиять на психические функции (внимание, память, воображение и способность к фантазии), межличностный тип отношений и тип взаимодействия, ценностные ориентации (Рубинштейн, 2002).

Полноценному развитию личности подростка способствует совокупность воспитательных ресурсов, которые использует педагог-хореограф в работе, а также создание специальных творческих условий обучающей среды:

- грамотность и культура поведения педагогов;

- контроль и управление культурой речи и поведением обучающихся;

- беседы о содержании национальных культур;

- создание новых и поддержание существующих традиций коллектива;

- посещение культурно-массовых мероприятий;

- участие в фестивалях и конкурсах искусств;

- направленность программы на комплексное развитие: умственное (интеллектуальное), физическое, нравственное, эстетическое (эмоциональное) воспитание (Комарова, 2000).

Занятия хореографией требуют большой работы над собой как физической, так и духовной. Только работая над собой, используя максимально свои возможности, силы и способности, ребенок продуктивно развивается. Особую роль в этом процессе играет выполнение наставником - хореографом правильно подобранных педагогических условий, обеспечивающих развитие и эффективность функционирования педагогической системы.

Педагогические условия отражают совокупность образовательных возможностей (специально разработанные меры воздействия и взаимодействия субъектов образования: содержание, методы, приемы и формы обучения и воспитания, программное и методическое оснащение образовательного процесса) и материально-пространственных (учебное оборудование). техническая, природно-пространственная среда образовательного учреждения и др.) среда, положительно или отрицательно влияющая на его функционирование (Ипполитова, 2012).

Эффективность формирования личности подростка на хореографических занятиях будет достигнута при следующих педагогических условиях:

- создании комфортной, доверительной атмосферы, психологически стабильной в отношениях между учащимся - учащимся и учащимся - педагогом;

- учете принципа доступности - построение занятий от простого к сложному с учетом возрастных и индивидуальных особенностях подростка;

- включении разнообразные средств и приемов: беседы (просмотр и анализ номеров своего коллектива, а также - других), лекции (построение постановочной работы, исторические справки о развитии танца и др.), концертной деятель- 
ности, развлекательных мероприятий для группы, использования сюжетно-ролевых игр, игровых упражнений;

- соблюдении принципа сознательности и активности - выработки системного посещения занятий;

- развитии коллектива через развитие индивидуальности подростка;

- развитии всесторонних качеств личности подростка (трудолюбие, настойчивость, ответственность, решительность, смелость);

- развитии самостоятельности у обучающихся - самостоятельно провести разминку в группах и индивидуально, придумать танец;

- развитии коммуникативных доверительных отношений, при которых у всех сторон есть возможность выражать свое мнение.

Для реализации данных условий полноценного развития подростка требуется разработка программы психолого-педагогического сопровождения на трех уровнях:

- технический подход;

- творческий подход;

- система ценностей.

Программа психолого-педагогического сопровождения, должна включать в себя процесс педагогического взаимодействия хореографа и ученика, направленного на целостное развитие ребенка через разнообразие образов и движений, рефлексии, через формирование у ребенка чувства самостоятельности, восполнения его жизненной энергии.

Развитие личности подростка на занятиях хореографией - это процесс, в котором соединяются воедино физическое и умственное, эмоциональное и интеллектуальное, общечеловеческое и специально-художественное, личное и общественное.

\section{СПИСОК ЛИТЕРАТУРЫ}

Ипполитова Н.В. (2012) Анализ понятия «педагогические условия»: сущность, классификация // General and Professional Education. №1. С. 8-14.

Комарова Т.С. (2000) Красота. Радость. Творчество. /Комарова Т.С., Антонова А.В., Зацепина М.Б. М.: Педагогическое общество России. С. 59-129.

Пуртова Т.В. (2003) Учите детей танцевать. / Т.В. Пуртова. М.: Владос. - 256 с.

Рубинштейн СЛ. (2002) Психология танца // С.Л. Рубинштейн. М.: Маренго. 496-500 c.

Зюкина Руслана Алексеевна - магистрант 3-го курса, кафедры педагогики и психологии высшей школы, Московского гуманитарного университета. Научный руководитель канд. психол. наук, доцент Е.Е. Иванова. Адрес:111395, Россия, г. Москва, ул. Юности, д.5. Тел.: 8 (901) 347-38-52. Эл. Адрес: rz280597@gmail.com 
Zyukina Ruslana Alekseevna 3rd year undergraduate student, Department of Pedagogy and Psychology of Higher Education, Moscow University for the Humanities. Scientific adviser Cand. psychol. Sci., Associate Professor E.E. Ivanova. Address: 111395, Russia, Moscow, st. Youth, 5. Tel .: 8 (901) 347-38-52. Email Address: rz280597@gmail.com 